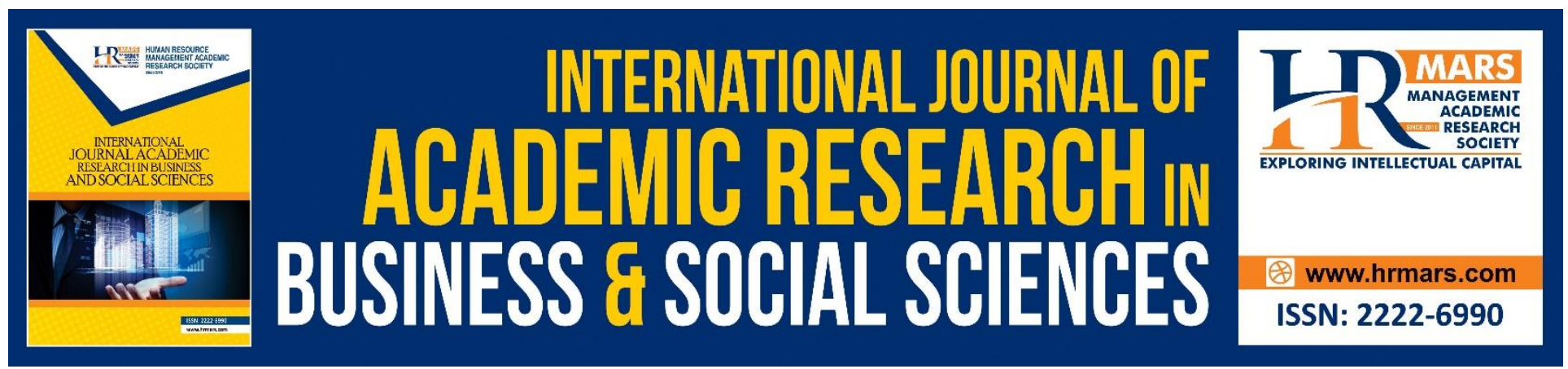

\title{
The Knowledge Development Concept in Humans: According to Sayyid Qutb's Perspective
}

Mohd Shafiee bin Hamzah, Mustaffa Abdullah, Mariam Nabilah Mohd Noor, Nor Hafizi Yusof \& Mohamad Zaidin Mat

To Link this Article: http://dx.doi.org/10.6007/IJARBSS/v8-i10/4729

DOI: 10.6007/IJARBSS/v8-i10/4729

Received: 12 Sept 2018, Revised: 24 Oct 2018, Accepted: 28 Oct 2018

Published Online: 31 October 2018

In-Text Citation: (Hamzah, Abdullah, Noor, Yusof, \& Mat, 2018)

To Cite this Article: Hamzah, M. S. bin, Abdullah, M., Noor, M. N. M., Yusof, N. H., \& Mat, M. Z. (2018). The Knowledge Development Concept in Humans: According to Sayyid Qutb's Perspective. International Journal of Academic Research in Business and Social Sciences, 8(10), 236-244.

Copyright: (c) 2018 The Author(s)

Published by Human Resource Management Academic Research Society (www.hrmars.com)

This article is published under the Creative Commons Attribution (CC BY 4.0) license. Anyone may reproduce, distribute, translate and create derivative works of this article (for both commercial and non-commercial purposes), subject to full attribution to the original publication and authors. The full terms of this license may be seen

at: http://creativecommons.org/licences/by/4.0/legalcode

Vol. 8, No. 10, 2018, Pg. 236 - 244

Full Terms \& Conditions of access and use can be found at http://hrmars.com/index.php/pages/detail/publication-ethics 


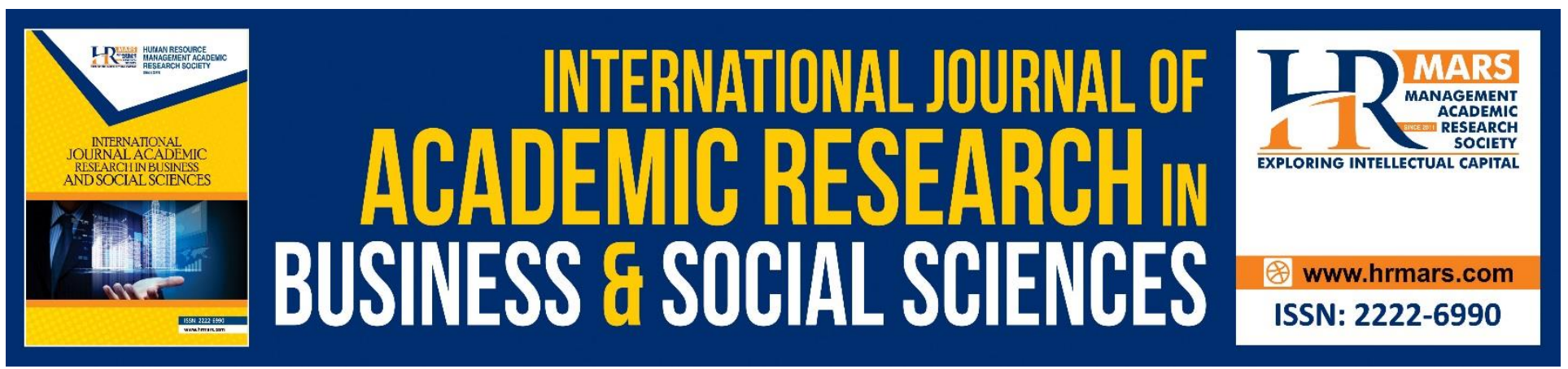

\title{
The Knowledge Development Concept in Humans: According to Sayyid Qutb's Perspective
}

\author{
Mohd Shafiee bin Hamzah, Mustaffa Abdullah, \\ Mariam Nabilah Mohd Noor, Nor Hafizi Yusof \& Mohamad Zaidin \\ Mat
}

Faculty of Islamic Contemporary Studies, Universiti Sultan Zainal Abidin, 21300 Gong Badak, Terengganu, Malaysia

\begin{abstract}
Knowledge is an important element that needs to be applied in the process of engineering human excellence in the world today. Contemporary global development has witnessed an economic paradigm from nature-based economy to knowledge-based economy. It is undeniable that there have been numerous discussions by intellectuals aimed at finding concepts related to knowledge, either in the West or East. Hence, this paper intended to analyse the views of a prolific Islamic thinker named Sayyid Qutb, pertaining to the knowledge concept that should be applied in the process of engineering human excellence. This study was qualitative in nature and used the document analysis method. Data for the document analysis was obtained from the basic text for this study, namely the Tafsir Fi Zilal al-Quran, with a focus on the interpretations by Sayyid Qutb related to knowledge. Then, by using the deductive approach, data were summarised according to several conclusions that were formed as knowledge concepts in the engineering of human excellence. This study found that the aspects of Islamic knowledge concept that should be applied in human engineering are, i) development of knowledge based on the spirit of the first divine revelation or iqra', ii) knowledge should be developed for the benefit of all, iii) divine revelation as the core of scientific knowledge, and iv) research based on the methodology of Quranic science.
\end{abstract}

Keywords: Concept of knowledge, Sayyid Qutb, Fi Zilal al-Quran, Divine Revelation

\section{Introduction}

The mind or intellect ( $a k a l)$ is an important gift bestowed by Allah s.w.t to humankind as khalifah on this earth. Armed with a thinking mind, humankind is capable of progressing far compared to other creatures. Ibn Khaldun (2000) stated that humans are social animals but they differ with animals as they are bestowed with a thinking mind and are able to converse. According to Islam, the responsibility of carrying out practices (taklif al-shar'i) is only called upon those who possess a sane thinking mind. Taklif al-shar'i is not required from those who are insane or those who do not possess 
a thinking mind. The function of the mind in relation to knowledge could be understood better from the analogy made by Al-Ghazali (2013), who stated that the mind is a nobility bestowed to the descendants of Adam by characterising the mind as a source of knowledge, such as the tree is the source for fruits, the sun is the source of light and the eyes are a source of sight. Hence, humans use the gift of the mind to achieve happiness on this earth and the afterlife as well as being a factor that differentiates humans from animals. Therefore, the gift of the mind to humans is an invaluable gift because it allows humans to develop knowledge and start to cultivate a natural habitat for life.

\section{Al-Quran and stimulation of the mind}

Al-Quran pays a lot of attention on the use of the mind. This can be seen when many verses in the alQuran frequently use the words "Don't you think", "Don't you understand?". "Don't you ponder" etc., which are verses that stimulate humans to use their thinking minds. In greater detail, the words yafqahun and yatafakkarun are each repeated 13 times in the al-Quran, whereas the word yatadabbarun is repeated twice and ta'qilun is repeated 24 times. Besides these words, the al-Quran also uses the words ulu albab and ulu al-absar, which are repeated 16 and 3 times respectively as well as directed at those who have an astute thinking mind. When the verses in the al-Quran were scrutinised according to the words above, the verses that stimulate the mind were divided into two, namely thinking about the verses in the al-Quran (al-ayat al-Qur'aniyyah) and thinking about the signs of the universe (al-ayat al-kauniyyah). Hence, it could be understood that all these words actually stimulate the human thinking mind to think, ponder and understand the religious decrees delivered by Allah through the al-Quran because the aim of the mind is to understand the wisdom in the verses delivered by Allah s.w.t, either the Quraniyyah or Kauniyyah verses.

\section{The Mind (akal) According to the Interpretation of Sayyid Qutb}

According to Sayyid Qutb (2009), among the qualifications for humans to become a khalifah is the strength of a conscious mind that is capable of making decisions. The strength of a conscious mind is the beginning of human responsibility as a khalifah on this earth because the khalifah's role is to evaluate and make decisions. He further explained that:

Besides the strength of the fitriah that pre-exists in humans, the strength of the conscious mind helps to think and determine the actions to be undertaken by humans. This pillar of strength helps boost the sense of responsibility in humans. Whoever uses this strength for sanctifying and cleansing oneself as well as developing good potential and overcoming weaknesses would benefit and lead to success. Conversely, if the individual puts to waste, hides it or weakens this strength, then the individual would fail and be on the losing end.

Thus, with the gift of a strong thinking capacity, humans are capable of making decisions, either to choose something positive (goodness) or negative (deleterious). This capability is very important because it allows humans to vindicate their choices. Humans have two options in determining their choices, which is either to follow the lead to do something good or make the wrong 
INTERNATIONAL JOURNAL OF ACADEMIC RESEARCH IN BUSINESS AND SOCIAL SCIENCES Vol. 8, No. 10, Oct. 2018, E-ISSN: 2222-6990 @ 2018 HRMARS

choice and get deviated. Strength of a thinking mind has moved humans far ahead compared to other creatures. Various innovations in life have been made by using this special medium bestowed by Allah s.w.t.

Therefore, Sayyid Qutb was of the view that the thinking mind also has certain limitations and boundaries. Thus, if the mind is left to innovate and be creative without any supervision, it has the potential to go astray. When commenting on the role of the mind, Sayyid Qutb stated that the mind received the commandments and it functioned to understand what was informed by the Prophets. When criticising the views of those who stated that only the mind is sufficient for seeking the truth in life, Sayyid Qutb stated that if that is the case then why did Allah s.w.t. send the Prophets to disseminate the book of Tauhid. For Sayyid Qutb, this is clear proof that the mind surely needs the guidance of divine revelation to carry out its function. Moreover, the mind, if used correctly, could drive humans to follow the correct path, while abusing the gifts from Allah s.w.t would force humans to face the wrath in the afterlife, as exhorted by Allah s.w.t. (Surah al-Mulk: 10-11):

"And they will say, "If only we had been listening or reasoning, we would not be among the companions of the Blaze. And they will admit their sin, so [it is] alienation for the companions of the Blaze"

Most of the mufassirin share the view of Sayyid Qutb when relating the verse above with the need for the mind to receive guidance from Allah s.w.t. Ibn Kathir (2000) stated that the verse above was related to the regret by the kafirs, namely that if they had a mind that could be benefitted or listen to what was delivered by Allah s.w.t, then they would not belong to the group comprising of the occupiers of Hell. Unfortunately, they did not understand the call by the Prophets and did not have a mind to drive them towards the truth. Al-Qurtubi (2006) added that this verse showed that the kafirs were not given any mind at all because the function of the mind is to receive the light and guidance. Whereas, Wahbah Zuhayli (1991) said that the regret by the kafirs and their self-blame was because of not using the sane mind, not thinking deep enough, comparing, studying and reaping the benefits as well as understanding the guidance. Hence, the actual function of the mind is to think deep enough, compare, study and reap the benefits as a platform for understanding the guidance delivered through the al-Quran. A mind that is not utilised well would impede its owner from seeing the truth.

\section{Development of Knowledge According to Sayyid Qutb}

After discussing the views of Sayyid Qutb pertaining to the priority of the mind in developing knowledge and its limitations in life, this section will discuss the concept of developing knowledge by humankind according to Sayyid Qutb's perspective. When looking into the text of the Tafsir Fi Zilal al-Quran, it could be concluded that several concepts on developing knowledge should be assimilated by humankind so that the knowledge that is built has a positive effect. Sayyid Qutb envisioned a huge catastrophe awaits humankind if they are not supplied with the actual knowledge. The discussion below is about several concepts of actual knowledge, like that debated by Sayyid Qutb in his interpretation called Fi Zilal al-Quran. 
INTERNATIONAL JOURNAL OF ACADEMIC RESEARCH IN BUSINESS AND SOCIAL SCIENCES Vol. 8, No. 10, Oct. 2018, E-ISSN: 2222-6990 @ 2018 HRMARS

\section{i- $\quad$ Development of Knowledge Based On the Spirit of The First Divine Revelation}

According to Sayyid Qutb, the first segment from the whole divine revelation delivered to the Prophet s.a.w did touch on the question of life centred on 'faith in monotheism' (tawhid) as the first fundamentals in determining the excellence of human life on this earth. This means that all activities in life need to begin with a sincere tawhid. Considering the priority of the Tawhid mechanism in human life, the duty of the Prophet s.a.w to deliver the final book to humankind began with the oath of tauhid, as mentioned by Sayyid Qutb (2009):

With the first segment that descended at the first second the relationship between the Prophet s.a.w and the highest order of Nature was formed, hence, the method of faith and type of thinking based on a faith that is strong and wide. All matters, movements, steps and actions are carried out by mentioning the name of Allah and in the name of Allah. In the name of Allah something is started and initiated. Everything heads towards and returns to Allah.

Clearly, the development of knowledge cannot escape from the main fundamental element, as found in the first divine revelation, which is the fundamental element of tauhid. Ismail al-Faruqi (1992) touched on this matter by emphasising on the importance of the tauhid framework that has an effect on the development of the individual, family and Muslims. This is also inline with the functions of the al-Quran, which encourages Muslims to use their mental strength in everyday life. The oath to read (iqra') in the first divine revelation is linked with the oath 'in my Gods name' (bismi rabbik), which is the highest manifestation of the importance of knowledge wrapped in the 'faith in monotheism' (akidah tauhid) and its role to Muslims. Hence, based on the explanation by Sayyid Qutb about the first divine revelation, it could be concluded that bestowing of the first divine revelation in the Hira' Caves shows that faith of tawhid is the pillar of the first divine revelation with the command to read (iqra') followed by 'name of the God, The Creator' (bi ism Rabbik allazi khalaq).

\section{ii- $\quad$ Knowledge for the Benefit of Humankind}

The second matter debated by Sayyid Qutb in his interpretations is how far the knowledge benefits the building of Islamic civilization. The mind bestowed by Allah s.w.t should produce knowledge that benefits humankind and not to destroy humankind. The mind should be used to harmonise this world by composing, cultivating and creating innovations in life. Thus, the process of cultivating, composing and innovating would not happen unless humankind uses the thinking mind to best benefit Muslims. Therefore, an individual's knowledge should be best used to get closer to Allah s.w.t and not distant oneself from Allah s.w.t. Sayyid Qutb (2009) stated:

At this time, humans had arrived at a level that was very developed based on the levels of development of knowledge with the success of producing the atom bomb and launching it. Hence, what gain is there for humans who possess knowledge such as this when they do not remind their fellow humans about Allah, are not afraid of Allah, do not praise Him and do not expose themselves with the knowledge to Him. What benefit do humans obtain from that knowledge besides creating 
INTERNATIONAL JOURNAL OF ACADEMIC RESEARCH IN BUSINESS AND SOCIAL SCIENCES Vol. 8, No. 10, Oct. 2018, E-ISSN: 2222-6990 @ 2018 HRMARS

violence and hatred, such as what happened in the Nagasaki and Hiroshima tragedies, spreading fear and anxiety among those in the East and West as well as threatening them with attacks and destruction.

The criticisms of Sayyid Qutb as mentioned above shows the effects of not using the mind for the benefit of humankind. What good is the development of modern knowledge when it produces weapons of mass destruction, such as the atom bomb? This means that when the benefit of knowledge is not given due attention, the discovery of modern knowledge, no matter how great it is, would be meaningless because it destroys and endangers humans. Hence, the explanation by Sayyid Qutb tells us about the importance of knowledge built for the benefit of humans. It should be developed by considering all universal human values and not based on hatred, as violence would lead to destruction.

\section{iii- $\quad$ Divine Revelation is the Pillar of Science}

The development of knowledge currently has seen fantastic scientific and technological discoveries. Space exploration has taken man to the moon. According to Sayyid Qutb, these discoveries should have brought humankind closer to Allah s.w.t in order to appreciate the might of Allah Taala as the Creator of the universe. Hence, the development of this modern world has separated the relation of knowledge from the original source of all knowledges i.e Allah Taala. This was described by Sayyid Qutb when debating verses 191-192 of Surah Ali-Imran, which is related to the phenomenon of nature. He said that:

However, if knowledge about nature that discusses the laws of the universe, the Prophet's s.a.w Sunnah as well as its contents and sources, related to zikir and remembering Allah s.w.t the Creator of the Universe and to feel His Greatness and His Blessings, then all activities related to knowledge would become a form of worship (Ibadah) to Allah, the Creator of the Universe. Conversely, the materialistic need built in the West has broken the relationship between nature and its Creator.

Sayyid Qutb's explanation above shows how his thoughts about knowledge built by the West does not connect humans to the Creator. Syed Nuquib al-Attas (1978) in his book "Islam and Secularism", had also commented about the rapid development of Western scientific knowledge today that has separated knowledge from its original source (Allah s.w.t). This process is known as the westernization of knowledge. The actions of the West have caused confusion in the world of knowledge because it has been separated from the original source. Prof. Hamka (2007) stated about the importance of integrating divine revelation and intellectual knowledge that was evident in subjects mentioned in the al-Quran. The Al-Quran has mentioned about the prowess of their intellectual knowledge by calling them the 'Ad people, who were skilled in building high-rise buildings; The Thamud, who had the expertise in transforming highlands or hills into homes and the "Pharoah had the pegs". Therefore, without combining intellectual knowledge and divine knowledge, this race would be destroyed by the retribution from Allah s.w.t. 
Therefore, it could be concluded that divine revelation should be the thrust of science in order to lead science towards the rightful path in life. Scientific knowledge that makes divine revelation as its thrust would be successful in bringing humans closer to The Supreme Creator.

\section{iv- $\quad$ Research Based on Quranic Scientific Methodology}

Research is an important activity that develops knowledge as well as produces various discoveries that could benefit humankind on this earth. In regards to research, there is a verse in the al-Quran, which according to Sayyid Qutb's interpretation, is related to research, namely the exhortation of Allah s.w.t in Surah al-Isra' verse 36, meaning:

"And do not pursue that of which you have no knowledge. Indeed, the hearing, the sight and the heart - about all those [one] will be questioned"

When describing that verse, Sayyid Qutb explained that when carrying out research there should be good intentions and a close relationship with Allah s.w.t. This is an added value to current researches that only think about material importance without focusing on the aspects of faith and piousness. Actually, as more researches are conducted, the relationship with Allah s.w.t should be closer. This is what Sayyid Qutb meant by the Quranic scientific methodology. Sayyid Qutb mentioned that:

It covers the scientific methodology that humans have discovered lately. This method has added value, whereby the theory for strengthening the intention and friendliness with Allah s.w.t. It is a special manhaj introduced by Islam and it is owned by the system or methodology of other intellectuals.

Sayyid Qutb's description about witnessing the act by all the sensory faculties, as exhorted by Allah s.w.t in the verse above, shows that the comprehensive al-Quranic scientific method is meant for all humans. The al-Quranic scientific method is very different from scientific methodology that exists in the West today because the al-Quranic scientific methodology puts the responsibility on every person involved in the research. Trust should be emphasised in every research because it would be questioned in the after-world.

When carrying out this study, faith and piousness towards Allah s.w.t should be the pillar in scientific research methodology in the world today. This is because, when seeking the truth, a study should be based on Allah, The Most Truthful. Thus, this is suitable with the spiritual belief of Islam that is built on confidence and never on a platform full of doubt and ambiguity. Clearly, confidence would never set foot in the heart of a person unless he possesses knowledge.

The difference between the Islamic and Western research methods were also elaborated by Prof. Dr. Osman Bakar (2008), when he talked about Islamic scientific research based on faith and piousness that produces a truthful and accurate outcome, which eventually proves the perfectness of Allah s.w.t., as the Creator of everything. 
Therefore, research methodology based on faith and piousness needs to integrate the heart and mind. A research methodology should not solely use the mind when determining the truth but instead, it should also involve the heart, which contains faith, because humans are responsible for the faculties of hearing, sight and feelings (heart) when confronting the Almighty who giveth them.

Hence, the al-Quranic scientific methodology demands that humans seek the truth with all their efforts and have a responsible attitude because humans are directed towards research and not to follow anything blindly. A high-quality research could be produced if it is built based on healthy thinking and a clean heart.

Sayyid Qutb gave an example of how Western scholars, such as Darwin, who had built his research based solely on the mind without being accompanied by honest intentions until his research eventually produced deviant results, such as humans having evolved from apes. He further stated that:

There is some good in mentioning that Darwin's development of the evolutionary theory had stated that various creatures had evolved from one essence of life in succession; and there were several evolutionary phases and relationships that are directly related with the theory that humans evolved from apes, which involved the hierarchy of apes that were the most genius and below the human hierarchy...it is the wrong theory. What more, after findings of the hereditary genes in humans until this theory became impossible...

This is one example of a research that does not have coordination between the heart and mind, until the mind had ventured far and eventually deviated from the actual path. Research findings that say that humans are creatures that evolved from apes is a finding that deviated far from the spirit of faith by lowering the status of humans to that of animals when humans are creatures glorified by Allah s.w.t as khalifah on this earth. This finding is contrary to the verse by Allah s.w.t, meaning, "and verily we have glorified Bani Adam ...." (Surah al-Isra': 70), which indicates that Allah s.w.t had glorified Bani Adam in a form of a beautiful creation, appointed as a khalifah and glorified with all the angels kneeling in respect.

Therefore, by using the knowledge approach, human engineering was initiated by making religion a strong platform for developing modern science. Hence, there is a need today for creating a group that has mastered divine revelation and intellectual knowledge. Mastering both these forms of knowledge would create a religious intellectual group that possesses a strong thinking mind as well as knowledge in the fields of religion, science, philosophy and technology. In the process of developing humans with a high level of knowledge, a suitable training regime should also be considered if humans wish to progress and compete at a higher level. 
INTERNATIONAL JOURNAL OF ACADEMIC RESEARCH IN BUSINESS AND SOCIAL SCIENCES

Vol. 8, No. 10, Oct. 2018, E-ISSN: 2222-6990 ㄷ 2018 HRMARS

\section{Conclusion}

Debate about the knowledge concept in human engineering according to Sayyid Qutb's perspective has produced several conclusions. First, Sayyid Qutb's opinion about the importance of the mind that should be developed in the Tauhid framework based on the spirit of the first revelation in Cave of Hira'. Second, the mind, if allowed to innovate outside the Tauhid framework would be deleterious to the world. Knowledge is not developed for the benefit of humankind anymore but developed to satisfy human greed. Third, development of science and technology lately should be based on divine revelation so that the knowledge is able to bring humankind closer to their creator. Fourth, the study of knowledge should be based on the scientific methodology of the al-Quran, which is not to deviate from the noble wishes of the al-Quran by solely using the mind but rather to combine the mind and faith.

\section{Acknowledgement}

Special appreciations to the Research Management, Innovation \& Commercialization (RMIC), Universiti Sultan Zainal Abidin (UniSZA) \& the Faculty of Islamic Contemporary Studies (FKI, UniSZA) for sponsoring the project.

\section{Corresponding Author}

Assoc. Prof Dr.Mohd Shafiee bin Hamzah, The Faculty of Contemporary Islamic Studies, The University of Sultan Zainal Abidin21300, Kuala Nerus, Terengganu Darul Iman.

\section{References}

Al-Faruqi, I.R. (1992). Tawhid And Its Implication For Thought And Life. Virginia: International Institute of Islamic Thought.

Al-Ghazali, A.B.M. (2013). Ihya' Ulum al-Din. Terj. TK. H. Ismail Yakub. Singapura:

Pustaka Nasional.

Al-Qurtubi, Abi Abdillah Muhammad bin Ahmad. (2006). Al-Jami' Al-Ahkam Al-Quran. Beirut: Muassasah al-Risalah.

Hamka. (2007). Tafsir Al-Azhar. Singapura: Pustaka Nasional.

IbnKathir, A.F.I. (2000). Tafsir al-Qur'an al-'Azim., Kaherah: Mu'assasah al-Qurtubah

IbnKhaldun. (2000). Muqaddimah Ibn Khaldun. Beirut: Dar al-Kutub al-'Ilmiyyah.

Bakar, O. (2008). Tawhid and Science Islamic Perspectives on Religion and Science. Shah Alam:

Arah Pendidikan Sdn. Bhd.

Qutb, S. (2009). Tafsir Fi Zilal al-Quran. Kaherah: Dar al-Syuruq.

Al-Attas, S.M.N. (1978). Islam and Secularism. Kuala Lumpur: Angkatan Belia Islam Malaysia.

Zuhaily, W. (1991). Tafsir Al-Munir. Beirut: Dar Al-Fikr Al-Mu'asir. 